\title{
Um lírico cismado e moderno: interpretação do Brasil no primeiro Drummond
}

A moody and modern lyrical poet: interpretation of Brazil in the first Carlos Drummond de Andrade ALEXANDRE PILATI*

DOI: https://doi.org/10.4322/principios.2675-6609.2022.163.008

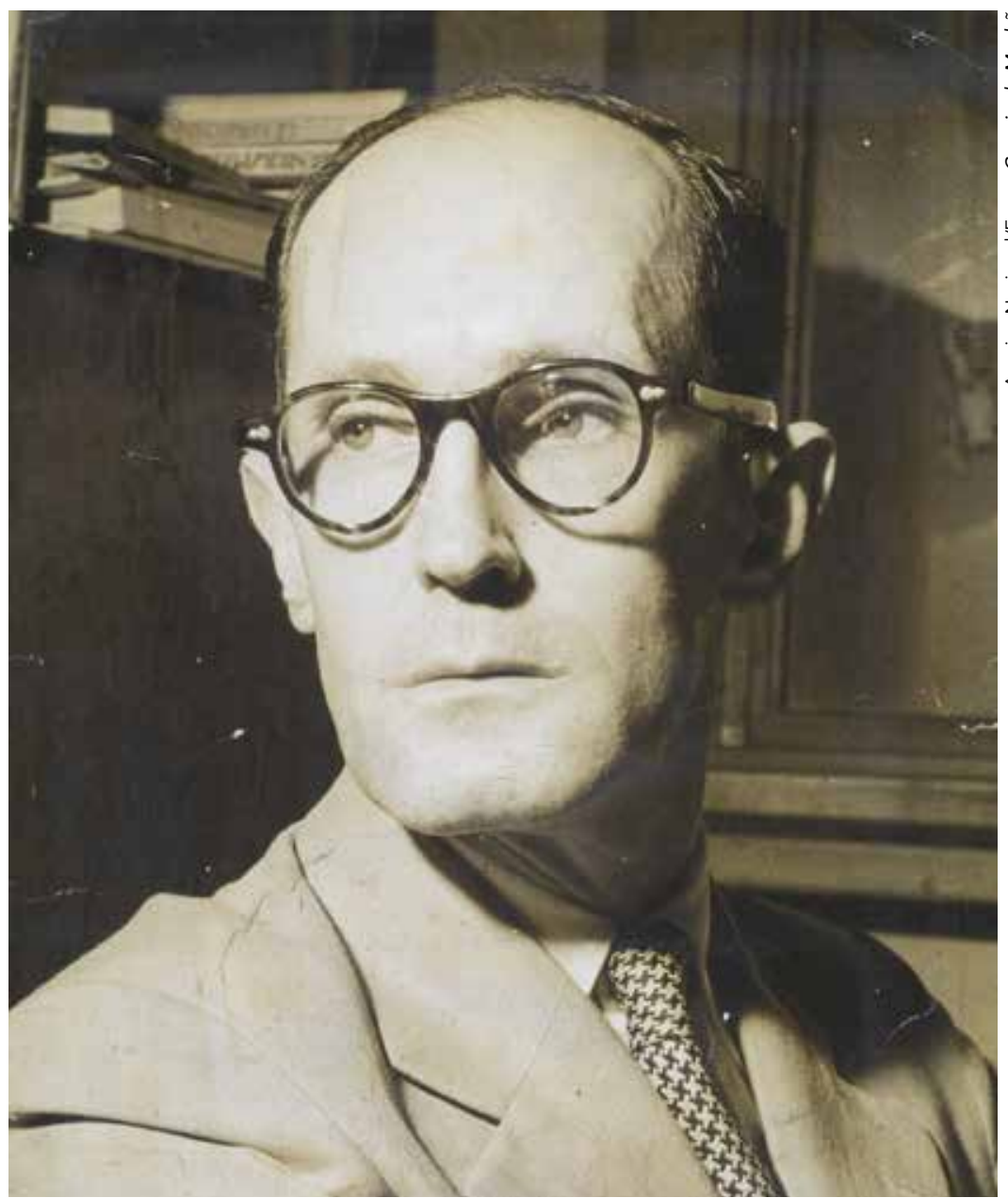

Carlos Drummond de Andrade (1902-1987), poeta mineiro, em foto de 1970 


\section{RESUMO}

Este artigo apresenta uma leitura dos primeiros livros de poemas de Carlos Drummond de Andrade, considerando-os como uma superação precoce das principais contradições do primeiro momento do Modernismo brasileiro, especialmente no que se refere à expressão de uma identidade nacional através do resgate de uma brasilidade não oficial, como pretendido pelos primeiros modernistas. A hipótese central do artigo é a de que a poética do jovem Drummond configura-se formalmente para evidenciar os limites do projeto modernista ao constituir sobretudo uma poesia de desconfiança do nacionalismo modernista e de problematização da vida brasileira.

Palavras-chave: Modernismo. Poesia brasileira. Carlos Drummond de Andrade. Identidade nacional.

\section{ABSTRACT}

This article presents a reading of Carlos Drummond de Andrade's first books of poems, considering them as an early overcoming of the main contradictions of the first moment of Brazilian modernism, with special focus on the expression of a national identity through the rescue of an unofficial Brazilianness as intended by the early modernists. The main hypothesis of the article is that the poetics of young Drummond are formally configured to highlight the limits of the modernist project by constituting itself above all as a poetry of distrust to modernist nationalism and by problematizing Brazilian life.

Keywords: Modernism. Brazilian poetry. Carlos Drummond de Andrade. National identity. 


\section{ENTRE CARLOS E MÁRIO}

Muita coisa na obra de Drummond o diferencia dos primeiros autores do Modernismo brasileiro. Em grande medida e sem exageros, sua poesia pode ser considerada mais moderna e menos modernista que a de Mário ou Oswald de Andrade. Sua lírica limpa-se de obrigações beligerantes e equaciona os dados da modernidade peculiar de um país tão difícil de definir como o Brasil. Livros como Alguma poesia e Brejo das almas, por isso, ganham a importância dos acontecimentos que dividem períodos e instauram novas diretrizes para o futuro. Investiguemos um pouco mais a fundo essa peculiaridade do poeta de Itabira.

Drummond, desde o início de sua vida literária, demonstrou preocupar-se com a realização de uma obra meditada a fundo e com meticulosidade. Não são poucos os autores que aludem ao cuidado do autor com a publicação de seu primeiro livro, Alguma poesia, que sai apenas em 1930. Os poemas desse livro foram produzidos bem antes e circularam, no estreito grupo de modernistas mineiros, a partir de 1925 , inicialmente em três números de A Revista, que divulgava o Modernismo em Belo Horizonte.

Muito tempo depois, nas conversas radiofônicas com Lya Cavalcanti que seriam publicadas sob o título de Tempo, vida, poesia: confissões no rádio, Drummond ainda lembraria os primeiros contatos com Mário:

Mário foi um caso especial, desses acontecimentos instantâneos, que nos fazem quase adivinhar o futuro: daí por diante haverá um elemento novo em nossa vida intelectual. Descobrimos um veio de ouro. Mas veio de ouro não define bem o que senti diante da figura literária dele. Não era riqueza a explorar, com maior ou menor esforço. Era riqueza dada sem condições, a não ser a de merecê-la por nós mesmos. $\mathrm{O}$ que Mário esperava de nós não era que o seguíssemos, mas que nos descobríssemos a nós mesmos, ao que pudesse haver de bom em nós, no sentido de inquietação, desejo de investigação e reflexão: queria (e foi explicitando isto nas cartas que passaria a nos escrever, paciente, pedagógico, obstinado) que adquiríssemos consciência social da arte e trabalhássemos utilitariamente nesse sentido, pela descoberta ou redescoberta gradativa do Brasil em nós, atualizados e responsáveis. Nunca segui a fundo a lição de Mário, mas o pouco de ordem (sob a desordem superficial) que passei a pôr no que escrevia é consequência da ação dele para me salvar do individualismo e do estetismo puro (ANDRADE, 2003b, p. I.246-I.247).

Veem-se, na fala do poeta, alguns elementos importantes para entender sua posição na história do Modernismo brasileiro. Primeiramente, a profunda ligação intelectual entre Carlos e Mário. Em seguida, a lição de empenho, que passa do paulista para o mineiro, com algumas adaptações. Por fim, vislumbra-se algo do projeto consciente de publicação que Drummond imprime a sua obra, sob os conselhos do amigo paulista. 


\section{A dimensão política dessa poética de interpretação do país reside no fato de que o Eu lírico de Drummond representa claramente um grupo social: o da oligarquia rural que tem de se reorganizar politicamente, a partir do início do século $X X$, ocupando a cidade por meio da indústria e da burocracia}

$\mathrm{Na}$ correspondência mantida com Carlos, Mário critica a obra do mineiro e aconselha-o até mesmo sobre a ordem dos poemas que se publicariam em Alguma poesia. As palavras de Mário são significativas: “'Explicação’ peso-pesado. Mesma coisa que 'Eu protesto' porém sem besteiras e muito mais melhor. Forte mesmo. Eu botaria isso no começo do livro que nem Prefácio." (ANDRADE, I988, p. 90) "Explicação" é, de fato, um dos poemas mais fortes do volume e, talvez, mais diretamente ainda do que o "Poema de sete faces", traduza o espírito do lirismo de Alguma poesia, o que mostra a consciência de Mário em relação à poética do amigo que lhe dedica o livro. Basta lembrar os versos de "Explicação":

Meu verso me agrada sempre...

Ele às vezes tem o ar sem-vergonha de quem vai dar uma cambalhota, mas não é para o público, é para mim mesmo essa cambalhota.

Eu bem me entendo.

Não sou alegre. Sou até muito triste.

A culpa é da sombra das bananeiras de meu país, esta sombra mole, preguiçosa. (ANDRADE, 2003a, p. 36)

A sintonia dos versos de "Explicação" com o Modernismo de Mário é evidente. Entre Carlos e Mário, portanto, como se vê, há um encadeamento que evidencia o vigor e os limites do sistema literário brasileiro. Por isso, a correspondência entre os dois é, certamente, um dos capítulos mais significativos da história da literatura brasileira. É um dos poucos momentos em que se realizou, às claras e de modo fundamental, a "passagem de bastão" que é tão cara à ideia formativa.

Drummond não começa da capo. Começa do diálogo demorado, profundo e profícuo com o mestre do primeiro momento modernista, ele próprio um dos intérpretes do Brasil de maior disposição e alcance analítico. Mário foi alguém que, como se pode perceber na fala de Drummond, quis fazer literatura - na esteira dos roman- 
cistas românticos - como "instrumento de descoberta e interpretação". Atesta-se isso, por exemplo, em trecho de outra carta do poeta de Pauliceia desvairada:

Nós temos que dar ao Brasil o que ele não tem e por isso até agora não viveu, nós temos que dar uma alma ao Brasil e para isso todo sacrifício é grandioso, é sublime. [...] A língua que escrevo, as ilusões que prezo, os modernismos que faço são pro Brasil [...] Os gênios nacionais não são de geração espontânea. Eles nascem porque um amontoado de sacrifícios humanos anteriores lhes preparou a altitude necessária de onde podem descortinar e revelar uma nação (ANDRADE, 2003b, p. 202-203).

Há, no alerta de Mário, um impressionante sentido da missão que deve passar de um escritor a outro e que configura algo sempre presente na produção poética de Drummond: a preocupação com o país. Esse sentido de missão, passando de Mário a seu correspondente mineiro, envolve a consciência da literatura como problema, o que mobilizou Drummond a lançar mão dos recursos modernistas não para tentar resolvê-lo, mas para aprofundá-lo, discutindo-o e estendendo-o até o limite.

O sentido de missão, talvez o melhor ensinamento do amigo Mário, fica bem claro na já famosa declaração presente em "Autobiografia para uma revista”, que integra o volume Passeios na ilha:

Entendo que poesia é negócio de grande responsabilidade, e não considero honesto rotular-se poeta quem apenas verseje por dor de cotovelo, falta de dinheiro ou momentânea tomada de contato com as forças líricas do mundo, sem se entregar aos trabalhos cotidianos e secretos da técnica, da leitura, da contemplação e mesmo da ação. Até os poetas se armam, e um poeta desarmado é, mesmo, um ser à mercê das inspirações fáceis, dócil às modas e compromissos (ANDRADE, 2003b, p. 929).

\section{O POETA E O PAÍS}

Ao que parece, toda a obra de Drummond (com especial ênfase nessa primeira fase) é um esforço para a desmistificação da situação do poeta e da sociedade brasileira. $\mathrm{O}$ passo decisivo que o mineiro dá para isso é rejeitar a poesia dita agradável, que compactua "com a sociedade que a transformou em privilégio" (COSTA, I993, p. 317). Rejeitando o agradável, Drummond opta pela violência. Uma violência nem sempre óbvia, direta ou contundente; uma violência que vem do fato de o poeta ter-se armado com a força dos problemas do indivíduo inserido na realidade nacional, nisso indo algo além dos primeiros modernistas. Em Drummond, o mundo patriarcal e a modernização periférica estão em primeiro plano. A lição da técnica de vanguarda, por sua vez, é utilizada como convenção consolidada envolta em espectro autocrítico.

A dimensão política dessa poética de interpretação do país reside no fato de que o Eu lírico de Drummond representa claramente um grupo social: o da oligarquia rural que tem de se reorganizar politicamente, a partir do início do século $\mathrm{XX}$, ocupando a cidade por meio da indústria e da burocracia, que ganham oportunidade e 
motor com o aprofundamento do movimento de desenvolvimento e industrialização do país. A voz que fala em Alguma poesia e em Brejo das almas, de certa forma, somatiza e antecipa essa experiência de rearranjo do poder político, condensando, no lirismo, o repertório de violência, atraso e injustiça que permanece sem superação, não obstante a modernização.

Nesse sentido é que se pode afirmar a presença de um outro realismo em Drummond. Um realismo, na perspectiva de Auerbach (2002), que está mais na sua capacidade de captar formalmente o movimento da sociedade que lhe foi contemporânea e menos no uso do retrato pitoresco do país.

O que chamamos de realismo drummondiano é uma representação da vida, com força capaz de equiparar-se à própria vida, não somente às representações literárias dessa mesma vida. A lírica de Drummond aparece como algo que está à altura dos conflitos da própria existência humana. O realismo drummondiano lembra o que afirma o Auerbach de Mimesis em sua caracterização do realismo do século XX:

o escritor atinge a impressão mencionada colocando-se a si próprio, por vezes, como quem duvida, interroga e procura, como se a verdade acerca da sua personagem não lhe fosse mais bem conhecida do que às próprias personagens ou ao leitor. Tudo é, portanto, uma questão de posição do escritor diante da realidade do mundo que representa (AUERBACH, 2002, p. 482).

Trata-se de uma representação do mundo e de si mesmo inquieta e pautada pela dúvida. Assim, o país apresentado por Drummond é o das classes sociais, mais do que a pátria pitoresca e mítica da "cor local". Seu realismo é soma de valor estético universal (dado o desembaraço no uso das conquistas estéticas da vanguarda) e conhecimento profundo da realidade histórica brasileira. Conforme afirma Lima (I995, p. I33), Drummond "se distingue pela apreensão consequentemente realista. Contra uma projetiva mítica, a sua obra propõe uma projetiva realista, marcada até as entranhas pela ideia de corrosão que desgasta seres e coisas."

\section{UM NOVO OLHAR BRASILEIRO}

Para enfocar a primeira poesia de Drummond como diferenciação do Modernismo heroico em termos formais, retomaremos uma afirmação de Lafetá (2004a) sobre o poeta. Segundo ele, encontramos algo nos versos drummondianos que não é verificado nos demais modernistas, não obstante o sentido de grupo que sempre animou a produção de todos eles, o qual fazia as saídas estéticas e ideológicas encontradas por um serem adotadas, transformadas e incorporadas por outro. Essa diferença, segundo Lafetá (2004a, p. 4I6), é

uma espécie de supervalorização do olhar e das imagens deste derivadas, a qual nada tem de pitoresco, e talvez — se a hipótese for plausível — seja mais reveladora de certos conflitos da subjetividade do poeta do que da ideologia modernista do Brasil como país novo, a ser redescoberto. 


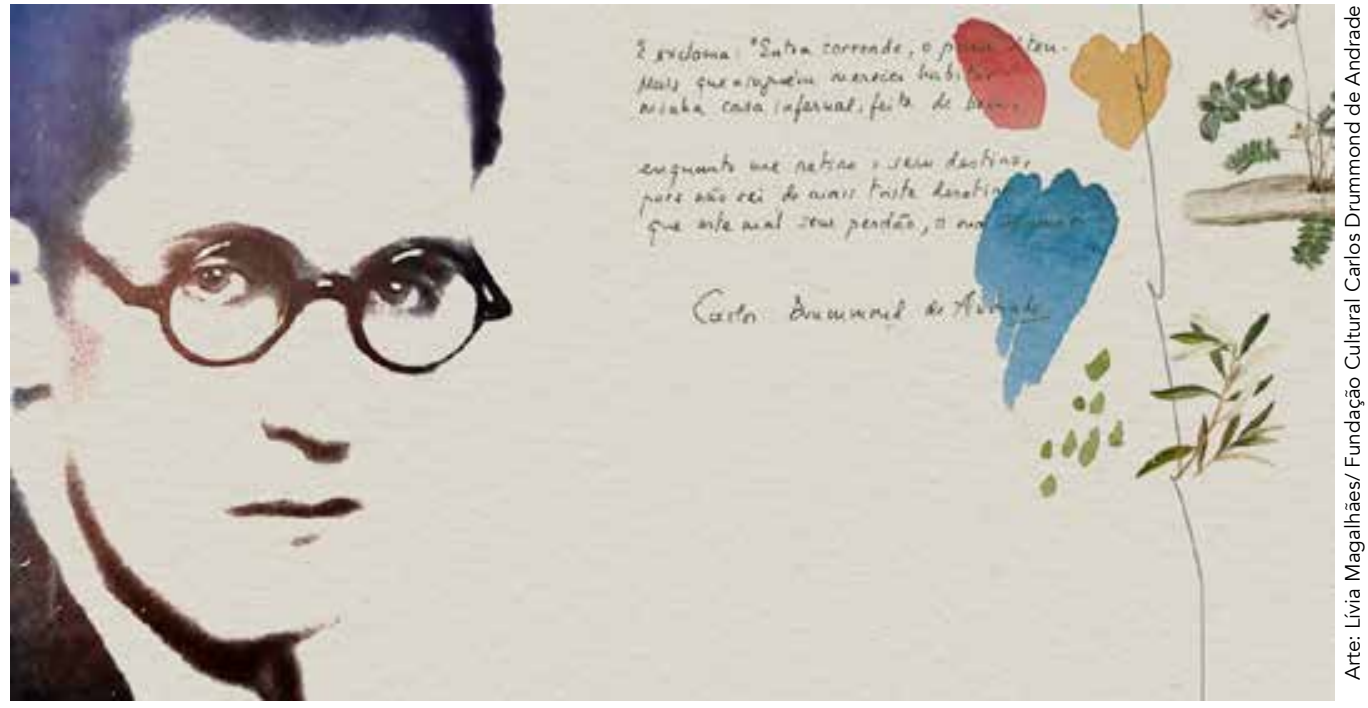

Para Lafetá (2004b), o olhar, especialmente na série de oito poemas sobre cidades intitulada "Lanterna mágica" de Alguma poesia, realiza um movimento lírico que promove a identificação entre o que está no Eu e o que se passa na paisagem. Assim, para além da nota localista de retrato do interior mineiro, "Lanterna mágica" expõe a identificação fundamentalmente lírica entre o Eu e a cidade. Essa identificação fica clara em "Belo Horizonte", primeiro poema da série. Leiamos outra vez o poema, verificando como é estabelecido o processo apontado por Lafetá:

Meus olhos têm melancolias,

minha boca tem rugas.

Velha cidade!

As árvores tão repetidas.

Debaixo de cada árvore faço minha cama, em cada ramo dependuro meu paletó.

Lirismo.

Pelos jardins de versailles

Ingenuidade de velocípedes.

E o velho fraque

na casinha de alpendre com duas janelas dolorosas.

(ANDRADE, 2003a, p. Io)

Lafetá (2004a) chama nossa atenção para o fato de que o texto está envolvido em um clima de ambiguidade e estranhamento conseguido graças à utilização da técnica bem modernista da superposição (a mesma do "Poema de sete faces"). De quem seriam os olhos melancólicos e as rugas da boca? Do Eu ou da jovem cidade de Belo Horizonte, que, à época da composição do poema, contava pouco mais idade que o poeta. Este tinha 25 anos; aquela completara apenas 30. A palavra lirismo corta o po- 
ema em verso rápido, como a evidenciar essa confusão: o Eu é a cidade, a cidade é o Eu. Lembremos também o poema "Coração numeroso":

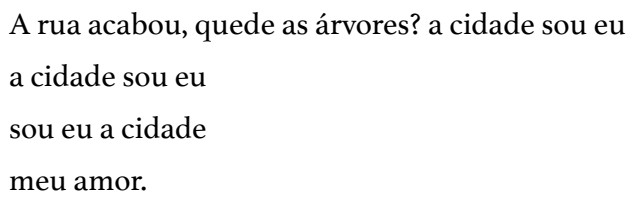

Ao final de "Belo Horizonte", há uma transfiguração que atesta bem a fusão enunciada em "Coração numeroso" de Eu e cidade: o Eu que fala se torna máscara e passa a ser referido em terceira pessoa. Essa máscara é formada imageticamente pela geometria da casinha de alpendre, onde as janelas são os dolorosos olhos do poeta.

A análise de Lafetá (2004a), rápida sem deixar de ser profunda, para por aí, deixando, entretanto, diversos caminhos críticos a que se pode dedicar o estudioso do Eu lírico drummondiano. Eis, no mínimo, um bom ponto de partida: o primeiro Drummond configura-se como superação do pitoresco modernista, uma vez que, pelo motivo do olhar, amalgama mundo e coração numa só nota especificamente brasileira. Assim, pode-se dizer que a interpretação do país nessa parte de sua obra chega mais pela via da natureza de seu lirismo e menos pela paisagem tipicamente mineira apresentada pelo conteúdo. Trata-se de uma poética que identifica Eu e cidade, alegorizando, no sentimento e na forma, a narrativa da nação e não descrevendo miticamente a "cor local" do país.

Explorando um pouco as pistas deixadas por Lafetá (2004a) a respeito do motivo do olhar, podemos levantar duas características de Drummond que ajudam a enxergar o poeta como um intérprete do Brasil que aprofunda as contradições do clima modernista. Uma delas é a via da ambiguidade e do estranhamento. A outra é a presença superposta velho/novo. Visto que Eu e cidade amalgamam-se, podemos dizer que essa ambiguidade de tom conseguida pelos procedimentos poéticos da vanguarda, associada a um fundo "sentimental" romântico, que chega ao leitor pela via do olhar, dá conta de uma realidade nacional ambígua e estranha. Isso, entretanto, não é necessariamente novidade em relação aos demais poetas do primeiro Modernismo. A novidade está na cunha que a persona ambígua coloca entre o código vanguardista e a representação do país. A ambiguidade é um dos vetores do sentido gauche drummondiano. À ambiguidade da forma, em "Belo Horizonte", corresponde uma ambiguidade de conteúdo, que apresenta uma sobreposição entre o velho e o novo.

Voltando a "Belo Horizonte", causam estranhamento as rugas na boca do poeta jovem, o adjetivo velho aposto à cidade tão nova (30 anos ainda!), o fraque, o alpendre da provinciana casinha mineira. Tudo isso está, aparentemente, a demonstrar, dolorosamente, que algo de arcaico permanece na novidade, como a casinha pitoresca que forma a face do moderno poeta. Isso se dá não apenas na paisagem, mas também na subjetividade que se apresenta ao leitor do poema. Na contraposição de vocábu- 


\section{DO OLHAR À CISMA}

Pelo motivo do olhar, chega-se a outro traço decisivo para o primeiro Drummond diferenciar-se dos primeiros modernistas: o seu caráter de "cisma". Arrigucci Jr.(2002) enfoca a característica "sentimental" drummondiana, conforme o sentido que dão à palavra os primeiros românticos, na esteira de Schiller. O termo sentimental, segundo ele, abarca não apenas sentimentalismo, como o sentido mais corrente da palavra pode sugerir. Trata-se de um "sentimento refletido", que se encontra na poesia dita "pensamentada", tão significativa no autor itabirano. Esse pensamento, assim como nos primeiros românticos, é autorreflexivo, pois representa um debruçar sobre si mesmo.

A reflexividade sentimental é percebida logo no primeiro texto de Alguma poesia, o famoso "Poema de sete faces", no qual se verifica um caráter eminentemente contraditório. A força da contrariedade é, de fato, um dos matizes mais característicos da lírica "pensamentada" de Drummond e sempre foi grifada por diversos críticos, desde Mário de Andrade (1960) e Antonio Candido (1995) até o próprio Arrigucci Jr. (2002). A persona sentimental que enuncia o discurso no poema de Drummond é, ao mesmo tempo, discreta e corrosivamente irônica; confidente e acintosa; agressiva e confessional, combinando, assim, gracejo e gravidade. Inquietudes típicas de um Eu que se incomoda com o próprio problema da expressão.

Esses são traços típicos do esforço intelectual de formação do país e de seu arcabouço de ideias. Por isso, propomos aqui outro nome para a "sentimentalidade reflexiva" romântica de Drummond. Cisma parece um bom termo para traduzir o modo especial de reflexividade drummondiana. Cisma significa "devaneio", "sonho", "fantasia", "absorção em pensamentos". Também pode significar "preocupação", “inquietação”. Conforme o uso popular brasileiro da palavra, cisma também indica "capricho", "teima”, "obstinação". Traços bem característicos do intelectual brasileiro, que se condensam no personagem já referido anteriormente, do poema "Itabira", o qual "só na porta da venda cisma na derrota incomparável".

Seguindo a ideia de "cisma" característica do Eu lírico, pode-se acrescentar à análise de Arrigucci Jr. (2002) o fato de que essa postura representa uma dificuldade de dar conta do país, própria não apenas do Modernismo do primeiro momento, mas também das grandes interpretações do país. A inquietude "cismada" em Drummond, então, pode ser sintoma de um problema "cognitivo", inerente à prática intelectual em um país como o Brasil. É um problema formativo, em última análise. Se uma das grandes questões do Modernismo era o desrecalque nacionalista, Drummond faz-lhe adendos: é possível conhecer o país que se deseja desrecalcar? Quais são os limites dessa empreitada intelectual? Em que medida, para os intelectuais, é possível conhecer o país que desejam retratar na literatura e no ensaísmo? A figura do Eu "encalacrado em situações aporéticas" (ARRIGUCCI JR., 2002, p. 59) não estaria alegorizando o encalacramento do próprio intelectual modernista? 


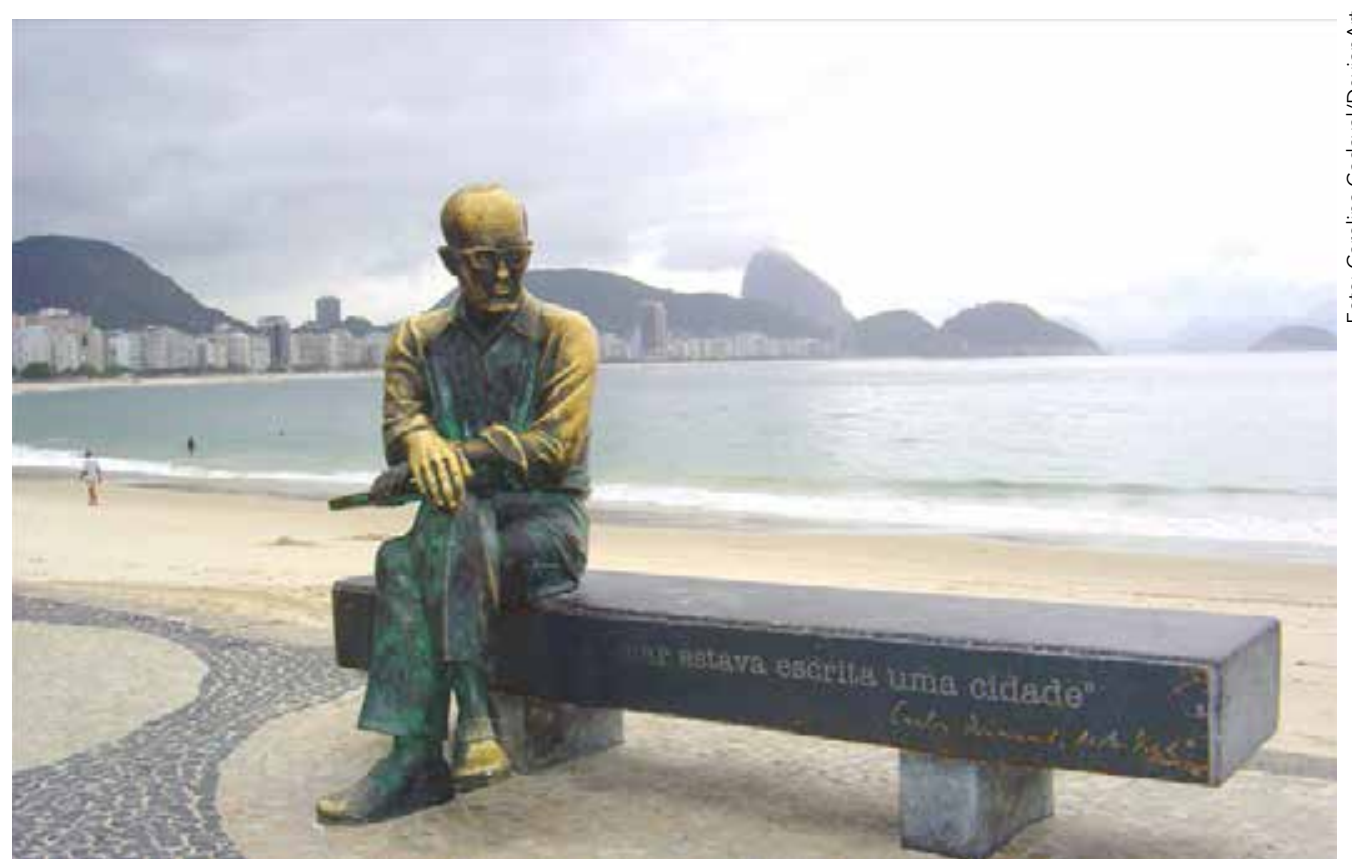

Estátua de Drummond no bairro de Copacabana, Rio de Janeiro (RJ)

Notemos como cisma e aporia são o tom de alguns dos versos mais lembrados de Alguma poesia e Brejo das almas. Basta lembrar, por exemplo, dos versos de "Sabará":

Eu fico cá embaixo

maginando na ponte moderna - moderna por quê?

$[\ldots]$

Ai tempo!

Nem é bom pensar nessas coisas mortas, muito mortas.

(ANDRADE, 2003a, p. Io)

A marcar as fronteiras desse encalacramento do Eu estão dois símbolos que figuram na experiência nacional e na poética de Drummond: a cidade e a província, que evidenciam, por sua vez, duas faces do Brasil que se atritavam de maneira evidente à época. Aludida na interpretação do poema "Belo Horizonte" realizada acima, a convivência atritante entre atraso e desenvolvimento é um catalisador da poética drummondiana e mostra que se o atraso não é superado, tampouco o desenvolvimento chega de maneira definitiva e ampla.

Mais do que tema, entretanto, arcaísmo e modernidade enfeixam a forma do poema, como se pode perceber tanto nos recursos de vanguarda associados a um tipo arcaico de romantismo sentimental quanto na construção rítmica dos versos dos poemas, que ora se estendem livres pelas estrofes, ora se regulam por métricas românticas e mais populares, ora se fraturam, confundindo verso livre e metrificação. Como afirma Costa (1993, p. 3II), o jogo de Drummond com os ritmos também tem função de "arma crítica". O atraso fica presente, então, no bojo do desenvolvimento brasileiro, dando-lhe motor e dinamismo. Eis uma nota específica do país, que a poética de 
Mais do que tema, entretanto, arcaísmo e modernidade enfeixam a forma do poema, como se pode perceber tanto nos recursos de vanguarda associados a um tipo arcaico de romantismo sentimental quanto na construção rítmica dos versos dos poemas, que ora se estendem livres pelas estrofes, ora se regulam por métricas românticas e mais populares, ora se fraturam, confundindo verso livre e metrificação

Drummond formaliza por meio dessa inquietude contraditória do Eu, que se revolve na aporia, não dando conta de apreendê-la por completo.

Desrecalcar o país, como queriam os modernistas, parece estar mostrando Drummond, era algo que envolvia considerar a luta de classes que garantia o nervo histórico da viragem cultural. Note-se, por exemplo, a explicação feita pelo poeta a respeito do título de Brejo das almas:

Brejo das Almas é um dos municípios mineiros onde os cereais são cultivados em maior escala. Sua exportação é feita para os mercados de Montes Claros e Belo Horizonte. Há também grande exportação de toucinho, mamona e ovos. A lavoura de cana-de-açúcar tem-se desenvolvido bastante. Ultimamente, cogita-se da mudança do nome do município, que está cada vez mais próspero. Não se compreende mesmo que fique toda a vida com o primitivo: Brejo das Almas, que nada significa e nenhuma justificativa oferece. D’A Pátria, 6/8/193I (ANDRADE, 2003a, p. 42).

Hoje o antigo município Brejo das Almas chama-se Francisco Sá e é a terra do alho. Retirada de um jornal da época, cujo tom é quase laudatório, e colada no seu livro, a citação feita por Drummond dá a ver o clima e os limites que uma "salvação onomástica" apresenta. Tal salvação é, no fundo, um microexemplo irônico da operação modernista de salvamento e mitificação do pitoresco brasileiro. Mudado o nome para Francisco Sá, a pequena cidade permaneceu afundada em um brejo histórico, que é a topografia alegórica por onde passeia o Eu lírico dos poemas do volume, refletindo o seu "coração maior que o mundo" e inquietando-se com ele. É como houvesse um alerta silencioso no trato de Drummond com a apreensão da técnica de vanguarda e com o desrecalque nacional perseguidos pelo primeiro Modernismo, conforme 
atestava a carta de Mário de Andrade citada anteriormente. Em Brejo das almas, vê-se uma forma de crítica ao Modernismo que, a seu modo, expõe algo semelhante ao que Roberto Schwarz (1987, p. 25-26) enxergou presente na poética de Oswald de Andrade:

Com os meios da literatura mais radicalmente anti-ilusionista, ou antiaurática, para falar com Walter Benjamin, Oswald procurou fabricar e "auratizar" o mito do país não oficial, que nem por isso era menos proprietário. Hoje todos sabemos que as técnicas da desidentificação brechtiana são usadas na televisão para promover a nossa identificação com marcas de sapólio. Por isso mesmo é interessante verificar que já ao tempo de sua invenção, quando o mordente seria máximo, esses procedimentos por si sós não bastavam para esquivar ambiguidades.

Talvez porque a questão não fosse "esquivar-se das", e sim "assumir as" ambiguidades. A ironia que aparece no recolhimento e colagem da citação noticiosa que inicia Brejo das almas é semelhante à dos poemas que compõem o livro e são forma literária e crítica que o discurso assume graças à inquietude do Eu lírico gauche. A gaucherie tem uma força histórica decisiva e um nome mais concreto: obliquidade. Oblíquo, ou seja, sinuoso e, às vezes, evasivo, é também o discurso do intelectual modernista encalacrado entre o projeto estético e o projeto ideológico do movimento, que resgatava um país não oficial, mas não "menos proprietário".

A obliquidade é caracterizada por Arrigucci Jr. (2002) na clivagem poética do chiste. Segundo ele, é o chiste que permite, com excelente resultado poético, conectar objetos distintos ou separados, ou mesmo evidenciar a discordância do que está aparentemente conectado. Em suas palavras, o chiste é "um modo de catalisar a poesia, apoiando-a numa forma de sintaxe capaz de juntar em liga estreita elementos divergentes e contrastantes" (ARRIGUCCI JR., 2002, p. 3I).

Acrescentamos aqui algo importante: se essa liga é estreita, não é totalmente homogênea, e o seu valor poético reside justamente no fato de que ela deixa ver certas costuras e contrastes que não desaparecem na operação de unificação da contrariedade promovida pela forma poética drummondiana. Há, pois, algo de irreparável na sua poesia, que pode dar a ver o irreparável do país. Não se pode esquecer o verso acima citado do poema "Aurora”, de Brejo das almas: “Tudo era irreparável." É um desconcerto que desconcerta e que está na fonte da violência contra o leitor em "Explicação":

Aquela casa de nove andares comerciais

é muito interessante.

A casa colonial da fazenda também era...

no elevador penso na roça,

na roça penso no elevador.

Quem me fez assim foi minha gente e minha terra

e eu gosto bem de ter nascido com essa tara.

(ANDRADE, 2003a, p. 36) 
Aí estão todos os elementos da poética drummondiana de interpretação nacional que até aqui foram delineados: a fratura de ritmo, a violência, a contrariedade, a cisma, o encalacramento do eu, o irreparável, o desrecalque local filtrado pela crítica e o retrato da subjetividade do filho-família dividido entre o arcaico e o moderno. Tudo isso crivado pela obliquidade, que marca a concentração que o Eu lírico drummondiano faz sobre si mesmo. A obliquidade geral de tom dá a esse pensamento autorreflexivo, entretanto, um leve tom de farsa, que tem a ver com a falta de poder do Eu para desempenhar a tarefa a que se propõe. Lendo Drummond, não se está diante de uma poética da certeza ou da afirmativa; mas sim do ceticismo, da dúvida, da sinuosidade.

Parece plausível, nesse sentido, a hipótese de Arrigucci Jr. (2002) segundo a qual, em Drummond, o Eu parece estar fantasiando sobre o próprio Eu, o que encaminha a leitura para a revelação do dilema de comunicar a multiplicidade contraditória do país, que, no caso do itabirano, se resolve pela representação formal e temática de um "equilíbrio tenso", prestes sempre a desabar, como a máscara do poema "Belo Horizonte", que, mal colocada, deixa ver seu propósito de artificialidade.

\section{UM ROMÂNTICO NO BREJO}

Os românticos, que o mineiro, de modo peculiar, recupera, acreditaram na espontaneidade como forma de revelar a intimidade e o país. Nos pequenos estudos que Drummond realizou em Confissões de Minas (1944) sobre poetas do Romantismo brasileiro, encontram-se diretrizes centrais de apreensão crítica da estética romântica que já se revelavam nos poemas de Brejo das almas. Tomado dessa forma, o volume de 1934 configura-se como uma das mais radicais interpretações de uma literatura em formação. Em Confissões de Minas, Drummond analisa a imperfeita solidão de Fagundes Varela, a "vulgaridade" de Casimiro de Abreu e o "sorriso" de Gonçalves Dias. Juntando esses três elementos tem-se um feixe de sentimentos que estrutura Alguma Poesia e, sobretudo, Brejo das almas.

Em que consiste cada um desses sentimentos: falsa solidão, "vulgaridade" e "sorriso"? Para Drummond, Fagundes Varela, embora tematize a solidão em inúmeros poemas e versos, não ama estar só. Conclui-se, pois, que a solidão aqui é código literário, que tem de ser cumprido de forma protocolar pelo poeta. Segundo Drummond (2003b, p. I75): "Ele pertence à espécie dos que não amam a solidão. Dos que têm medo dela. Alguns dos seus versos, aqui e ali, denunciam certo desapontamento, certa irritação produzida pelos contatos infelizes com o mundo." Drummond conclui que Varela era um homem preso a outros homens e que isso foi impossível esconder em seus versos, embora o desejo de atender à necessidade da convenção literária romântica o tivesse forçado a tematizá-la em sua obra. O poeta mineiro conclui, pois, que essa inversão de sinal que Varela opera é o que dá valor à poesia. Não se trata de um romântico que nega o mundo em favor de si, trata-se de um romântico que não se coaduna à solidão e não sabe por que o mundo o recusa. 
Essa figura de poeta preso a uma situação incômoda é recorrente em Brejo das almas, formalizando-se sob um tom de desilusão com a convenção, que expõe a impossibilidade de superá-la, como em "Um homem e seu carnaval":

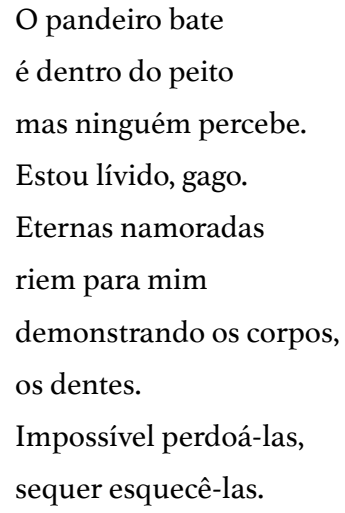

Em Casimiro de Abreu, Drummond analisa a grande capacidade de vulgarização da poesia. A grandiosidade do poeta, para Drummond, estaria no fato de ele produzir uma poesia que qualquer um se pode achar capaz de produzir. Segundo ele: "O encanto de Casimiro de Abreu está na tocante vulgaridade. Em sua poesia tudo é comum a todos." (ANDRADE, 2003b, p. I78) Drummond chega a elencar os três temas acerca dos quais sempre fala Casimiro, para além dos quais sua poesia não vai: “a) o homem se recorda de sua infância e fica triste; b) o homem tem um amor que não pode realizar-se e fica triste; c) o homem está longe de sua terra natal e sente saudade" (ANDRADE, 2003b, p. I78). Com timbres críticos, essa temática é recuperada em Brejo das almas, como se pode ver, por exemplo, em "O passarinho dela":

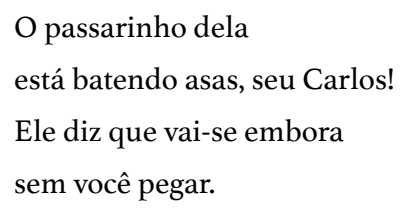

Por fim, o "sorriso" de Gonçalves Dias, para Drummond, constitui-se naquilo que se pode considerar um leve efeito cômico produzido na leitura contemporânea da obra do poeta. Nas palavras de Drummond: "Gonçalves Dias aí nos apresenta o edificante e o épico debaixo de um certo pitoresco, que lhe reduz as proporções, humanizando-as" (2003b, p. I83). Essa visão de comicidade que se extrai da leitura contemporânea dos grandes feitos românticos está de certa maneira formalizada em um texto como "Hino Nacional", por exemplo.

Estão aí três elementos que Drummond enxerga nos românticos e que são reaproveitados por ele próprio para o equacionamento da sua própria forma poética. Românticos que fizeram do desvio da norma geral romântica o valor de interesse que 


\section{Desrecalcar o país, como queriam os modernistas, parece estar mostrando Drummond, era algo que envolvia considerar a luta de classes que garantia o nervo histórico da viragem cultural}

podem gerar para os brasileiros do presente. Todos são casos de transgressão da norma europeia do Romantismo, ou de "ideias fora do lugar": no primeiro caso, uma solidão que não se quer solitária; no segundo caso, uma renúncia dos temas edificantes e da originalidade em favor de uma poesia de qualquer um para qualquer um; no terceiro, um tom de pitoresco e desacerto que fratura o épico.

Observando esses elementos e os volumes Alguma poesia e Brejo das almas, podemos perceber que Drummond investigava a fundo a brasilidade fixada pelas obras românticas e que ele tratava de, à maneira modernista, explorar as possibilidades artísticas desse descompasso, revelando-o e dando-lhe continuidade, inserindo outro elo na cadeia formativa da literatura brasileira.

É como afirma Teixeira (2005, p. 79): "o poeta mineiro, de seu mirante periférico, acusa a falência de todo um sistema político e ideológico que só se aclimatou no trópico natal de modo rudimentar e não raro farsesco".

Por isso, não se pode desconsiderar que tal movimento se dá em Drummond com o sinal negativo também embutido no discurso. A obliquidade drummondiana, por exemplo, põe uma marca quase cínica na enunciação. Drummond dissecou o mito da espontaneidade romântica em seus textos sobre poetas românticos brasileiros. Esse talvez seja o tema geral de Brejo das almas, que conta, entre os seus textos mais significativos, com um "Soneto da perdida esperança" dizendo obliquamente: "Não sei se estou sofrendo/ ou se é alguém que se diverte."

A troca das pessoas, de um verso a outro, desconcerta o leitor. O Eu do primeiro verso é, na verdade, o mesmo Eu do segundo, referido obliquamente pela indeterminada terceira pessoa indicada por alguém. Farsa, disfarce, desilusão, finta: é o questionamento do poder daquele que enuncia. Lida como oblíqua, a voz lírica em Drummond assume uma característica histórica que dá a ver o grão de privilégio que macula as melhores intenções interpretativas da realidade do país. Talvez a voz drummondiana esteja querendo revelar que o país se conhece melhor pelo prisma oblíquo, através do qual se observa que a incerteza, a impossibilidade e a negatividade são mais produtivas do que a festa certeira e positiva de boa parte do culturalismo modernista.

E tudo isso é realizado no já referido tom de conversa, de intimidade, de confidência. Esse tom íntimo, amigo, pessoal, foi enfocado por Teixeira (2005) como índice da cordialidade do Eu lírico de Drummond. Em Brejo das almas, é como se, de fato, o leitor se visse diante de um "camarada". Segundo Teixeira (2005, p. 75): "É como se o poeta 
cordialmente pusesse a mão no ombro do leitor e o chamasse para um bar, onde os dois pudessem abrir o peito um para o outro."

Mas essa cordialidade não é espontânea. Há uma ironia fortíssima e sutil, encobrindo versos como os de "Convite triste":

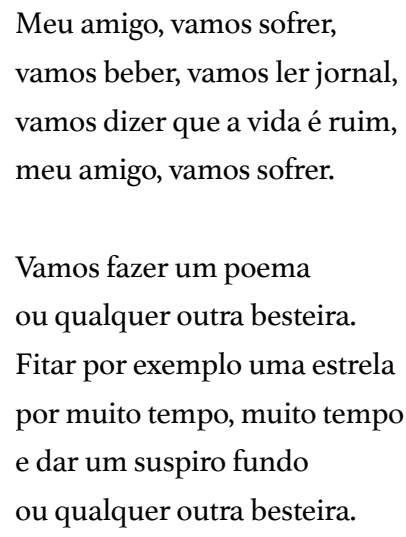

(ANDRADE, 2003a, p. 56)

Conforme afirma Teixeira (2005), as sugestões dadas pelo Eu lírico ao seu amigo leitor são apenas clichês, placebos "para uma dor que não amaina" (TEIXEIRA, 2005, p. 75). A dor que não amaina é a de encontrar-se o país no brejo histórico, uma topografia política que diz respeito à incapacidade brasileira para implementar a imparcialidade na esfera pública. Eis o brejo histórico descrito por Drummond, com a ajuda de recursos recuperados dos românticos. Vai aqui trabalhada, noutras cores, a dicotomia entre norma impessoal e impulso afetivo destacada por Sérgio Buarque de Holanda no modo de ser ou na estrutura social e política, para analisar e compreender o Brasil e os brasileiros. Não é despropositado dizer que há em Drummond, especialmente em Brejo das almas, uma crítica ao homem cordial, conceito que pressupõe o predomínio de comportamentos de aparência afetiva, inclusive suas manifestações externas, não necessariamente sinceras nem profundas, que se opõem aos ritualismos da polidez. $\mathrm{O}$ homem cordial é visceralmente inadequado às relações impessoais que decorrem da posição e da função social do indivíduo, e não da sua marca pessoal e familiar, das afinidades nascidas na intimidade dos grupos primários. É o intimismo e a inadequação à norma que Drummond sublinha nos textos de Confissões de Minas em que fala dos românticos.

Tendo em vista tudo isso, o Brejo das almas que está desenhado nos poemas não poderia ser considerado o endereço poético da cordialidade? Tudo nesse volume parece indicar a construção simbólica da cordialidade. Recordemos algumas palavras de Sérgio Buarque de Holanda a esse respeito:

No "homem cordial", a vida em sociedade é, de certo modo, uma verdadeira libertação do pavor que ele sente em viver consigo mesmo, em apoiar-se sobre si próprio em todas as circunstâncias da existência. Sua maneira de expansão para com os outros reduz o indivíduo, cada vez mais, à parcela social, periférica, que no brasileiro como bom brasileiro - tende a ser a que mais importa. Ela é antes um viver nos outros (HOLANDA, 2002, p. I.05I). 
É preciso perceber, entretanto, que essa cordialidade é vivida em cada poema de Brejo das almas sempre atravessada por uma obliquidade crítica. O Eu lírico posiciona-se sempre como se ironizasse o modo de estar só, desejando vivenciar o público como familiar. Drummond, em Brejo das almas, mergulha, pois, criticamente, naquilo que Sérgio Buarque de Holanda afirmou ser o aspecto central do comportamento brasileiro: "a ética de fundo emotivo" (HOLANDA, 2002, p. I.052).

Costa (1993) explica o Drummond do "Poema de sete faces" valendo-se um pouco dessa noção de obliquidade crítica, dando raiz histórica à multiplicidade de máscaras que se oferecem ao leitor. Diz Costa (1993, p. 313):

a fragmentação da subjetividade, ou a multiplicação do "eu" (tópico obrigatório das vanguardas europeias), é formalizada, expondo a diversidade de máscaras de que se reveste a problemática aventura individualista das nossas classes dominantes

Na mesma trilha da recuperação do Romantismo que anteriormente se apresentou, Costa (1993) estabelece uma relação entre as sete faces do poeta itabirano e as duas faces explicitadas pelo romântico Álvares de Azevedo. Segundo ela, Azevedo podia assumir a sua poesia como uma verdadeira medalha de duas faces. A Drummond, todavia, era possível jogar com sete faces ao mesmo tempo, quando interessava "problematizar as máscaras do individualismo em nossa experiência histórica" (COSTA, I993, p. 314). Uma dessas máscaras mais violentas está, conforme Costa (I993), representada no poema "Iniciação amorosa", o qual, narrando a experiência sexual desastrada do filho-família com a lavadeira "morena", mostra a perversa ociosidade voluptuosa das classes dominantes. O poema se torna, assim, uma explicação notável "do exercício da brutalidade contra mulheres por certo tipo de homem brasileiro, expondo-lhe o fundamento numa específica relação de classe" (COSTA, I993, p. 316):

E como eu não tinha nada que fazer vivia namorando as pernas morenas da lavadeira

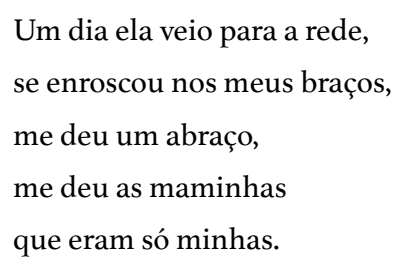

A alguns críticos, como se viu, não escapa a substância histórica da violência e da multiplicidade de faces, ou máscaras, que assume o Eu lírico de Drummond a partir do poema de abertura de sua carreira literária em Alguma poesia. O que desejamos aqui reforçar é que a gaucherie, lida tantas vezes - e não incorretamente - como incômodo e inadequação, é, sobretudo, representação de uma personalidade oblíqua típica das classes proprietárias brasileiras e da intelectualidade nacional. Trata-se de um sentimento de gume duplo: é crítica e também defesa de classe. 


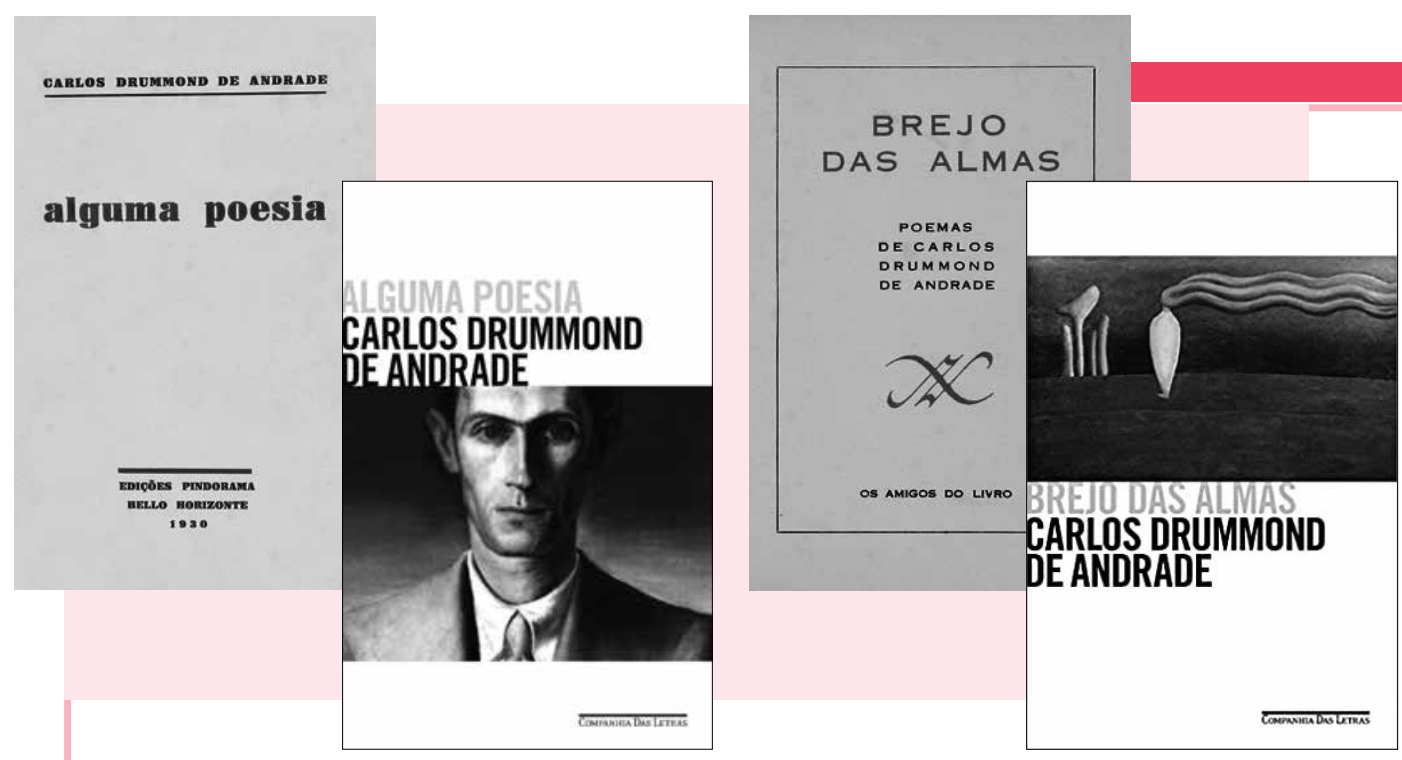

O moderno patrocinado pelo arcaico encontra assim figuração na sua primeira poesia. Alguma poesia e Brejo das almas antecipam algumas discussões que se vão aprofundar na literatura a partir de 1930. Mesmo sem trabalhar decisivamente com aquilo que foi mais característico nessa literatura, ou seja, a descrição do operário, do camponês, a denúncia dos males sociais, o primeiro Drummond problematiza de modo profundo a agudização da consciência política

\section{UMA POÉTICA DE ALTO VOLUME FORMATIVO}

Até aqui mostramos que a lírica "cismada" do primeiro Drummond mimetiza o papel do intelectual modernista, dividido entre o projeto modernista e a persistência do arcaico cordial, na base de sua substância ideológica. $\mathrm{O}$ moderno patrocinado pelo arcaico encontra assim figuração na sua primeira poesia. Alguma poesia e Brejo das almas antecipam algumas discussões que se vão aprofundar na literatura a partir de 1930. Mesmo sem trabalhar decisivamente com aquilo que foi mais característico nessa literatura, ou seja, a descrição do operário, do camponês, a denúncia dos males sociais, o primeiro Drummond problematiza de modo profundo a agudização da consciência política. Retomemos a conclusão de Lafetá (2004b, p. 64): 
Dentro disso podemos concluir que, se a ideologia do "país novo" serve à burguesia (que está em franca ascensão e se prevalece, portanto, de todas as formas - mesmo destrutivas - de otimismo), a consciência (ou a pré-consciência) pessimista do subdesenvolvimento não se enquadra dentro dos mesmos esquemas, já que aprofunda contradições insolúveis pelo modelo burguês.

Longe de "aderir" à ideologia de país novo, a lírica drummondiana, que em livro já nasce amadurecida pelas lições do amigo Mário, está perto de arquitetar formalmente um comentário sobre essa pré-consciência do subdesenvolvimento diante da insolubilidade das contradições do país.

Tal consciência pessimista do subdesenvolvimento começa a se tornar forma lírica com a mudança de ênfase operada por Drummond. Contrapostos ao tom mais vital, eufórico e humorístico do Modernismo por assim dizer "paulista", Alguma poesia e Brejo das almas marcam-se por um pessimismo que se revela como desencanto individual pelo viés da autoironia. Encontramos também no primeiro Drummond o prenúncio das obras que ele daria a lume na década seguinte, mais comumente consideradas obras de participação: Sentimento do mundo (I940), José (I942) e A rosa do povo (I945). Entre os livros dos anos 1930 e 1940, encontra-se muito em comum, pois desde Alguma poesia até A rosa do povo há uma "trituração do aconchego poético" (LIMA, I995).

Os sentimentos de angústia, asco, desgosto que recobrem a situação de "cisma" do Eu encalacrado ajudam a enxergar Drummond como um autor realista em sentido amplo, que mimetiza o processo de formação da condição brasileira como um todo, tomando as "providências" de um analista do Brasil. A primeira dessas providências parece residir no fato de que o poeta mineiro está de olho nos românticos, a fim de recuperá-los poeticamente, não pela via do nacionalismo pitoresco, mas sim pela via crítica. Dessa forma, Drummond colocava um grão de crítica no Neorromantismo pitoresco modernista. A confiança total no Eu, típica do pacto romântico, é fraturada pela obliquidade lírica, que vai criando máscaras evidentemente artificiais e cambiantes. Assim, o poeta não preteria o vínculo local (colocado criticamente em primeiro plano), pois fazia o eu vivenciar os limites da cordialidade e não se deixava levar totalmente pelo cosmopolitismo das vanguardas.

Enfocando o processo formativo, vemos que a interpretação drummondiana inclui a formalização da problemática de que se imbuiu o Modernismo como momento crítico de nossa história literária. Essa problemática envolve o culturalismo modernista, a revolução estética que se intentava operar e a questão de classe que permanecia irresolvida em uma revolução estética patrocinada pela burguesia rural. A herança romântica fraturada por Drummond dava continuidade a um campo de problemas reais e particulares tipicamente brasileiros.

Esse campo de problemas está formulado ainda na obliquidade lírica da voz que cisma por trás do painel nacional que se abre em primeiro plano ao leitor. Talvez estivesse o poeta mostrando ao Brasil que era impossível "saltar sobre a própria sombra" (ARANTES, P.; ARANTES, O., 1997), expondo a ideia de que o desacerto político da nação não se curava com o desrecalque cultural. A obliquidade do Eu lírico em Drum- 
mond indica, portanto, que a primeira fase do Modernismo cumpriu seu objetivo, em termos de trabalho com a convenção poética cosmopolita que operou a renovação do código; mas também no que desejava a classe dominante em termos de projeto de hegemonia, a fim de acomodar-se à nova situação socioeconômica.

Isso inseria, entretanto, o próprio intelectual em uma situação aporética, mimetizada também pela lírica drummondiana. Alguma poesia e Brejo das almas são livros em que a "cisma", a obliquidade e o encalacramento do Eu cordial (e não a confiança e a espontaneidade dele) simbolizam os dilemas de toda uma classe, antecipando, assim, algo do Modernismo social dos anos 1930 e configurando-se como lírica política de imensa qualidade poética.

* Professor de Literatura Brasileira da Universidade de Brasília (UnB). Mestre e doutor em Literatura pela UnB com pós-doutorado pela Universidad de Buenos Aires (UBA). Foi professor visitante da Università degli Studi di Perugia, Itália. Autor, entre outros livros, de A nação drummondiana e Poesia na sala de aula. E-mail: alexandrepilati@unb.br

Texto recebido em 24 de novembro de 2021; aprovado em 26 de novembro de 2021.

ANDRADE, Carlos Drummond de. A lição do amigo: cartas de Mário de Andrade a Carlos Drummond de Andrade. Rio de Janeiro: Record, 1988.

Poesia completa. Rio de Janeiro: Nova Aguilar, 2003a.

Prosa seleta. Rio de Janeiro: Nova Aguilar, 2003b.

ARANTES, Paulo Eduardo; Arantes, Otilia B. F. Sentido da formação. São Paulo: Paz e Terra, 1997.

ARRIGUCCI JR., Davi. Coração partido. São Paulo: Cosac \& Naify, 2002.

AUERBACH, Erich. Mimesis: a representação da realidade na literatura ocidental. São Paulo: Perspectiva, 2002.

COSTA, Iná Camargo. A herança modernista nas mãos do primeiro Drummond. In: PIZARRO, Ana (Org.). América Latina: palavra, literatura e cultura. São Paulo: Memorial; Campinas: Unicamp, 1993. p. 309-318.

HOLANDA, Sérgio Buarque de. Raízes do Brasil. In: SANTIAGO, Silviano (Coord.). Intérpretes do Brasil. 2. ed. Rio de Janeiro: Nova Aguilar, 2002. v. 3. p. 927-1.102.

LAFETÁ, João Luiz. A representação do sujeito lírico na Pauliceia desvairada. In: PRADO, Antonio Arnoni (Org.). A dimensão da noite. São Paulo: Duas Cidades; Editora 34, 2004a. p. 348-372.

Duas janelas dolorosas: o motivo do olhar em Alguma poesia e Brejo das almas. In: PRADO, Antonio Arnoni (Org.). A dimensão da noite. São Paulo: Duas Cidades; Editora 34, 2004b. p. 414-420.

LIMA, Luiz Costa. O princípio-corrosão na poesia de Carlos Drummond de Andrade. In: Lira e antilira: Mário, Drummond, Cabral. Rio de Janeiro: Topbooks, 1995. p. 129-196.

SCHWARZ, Roberto. Nacional por subtração. In: Que horas são?. São Paulo: Companhia das Letras, 1987. p. 29-48.

TEIXEIRA, jerônimo. Drummond cordial. São Paulo: Nankin Editorial, 2005. 